\title{
Stentor coeruleus
}

Do these tiny cells have out-of-body experiences?

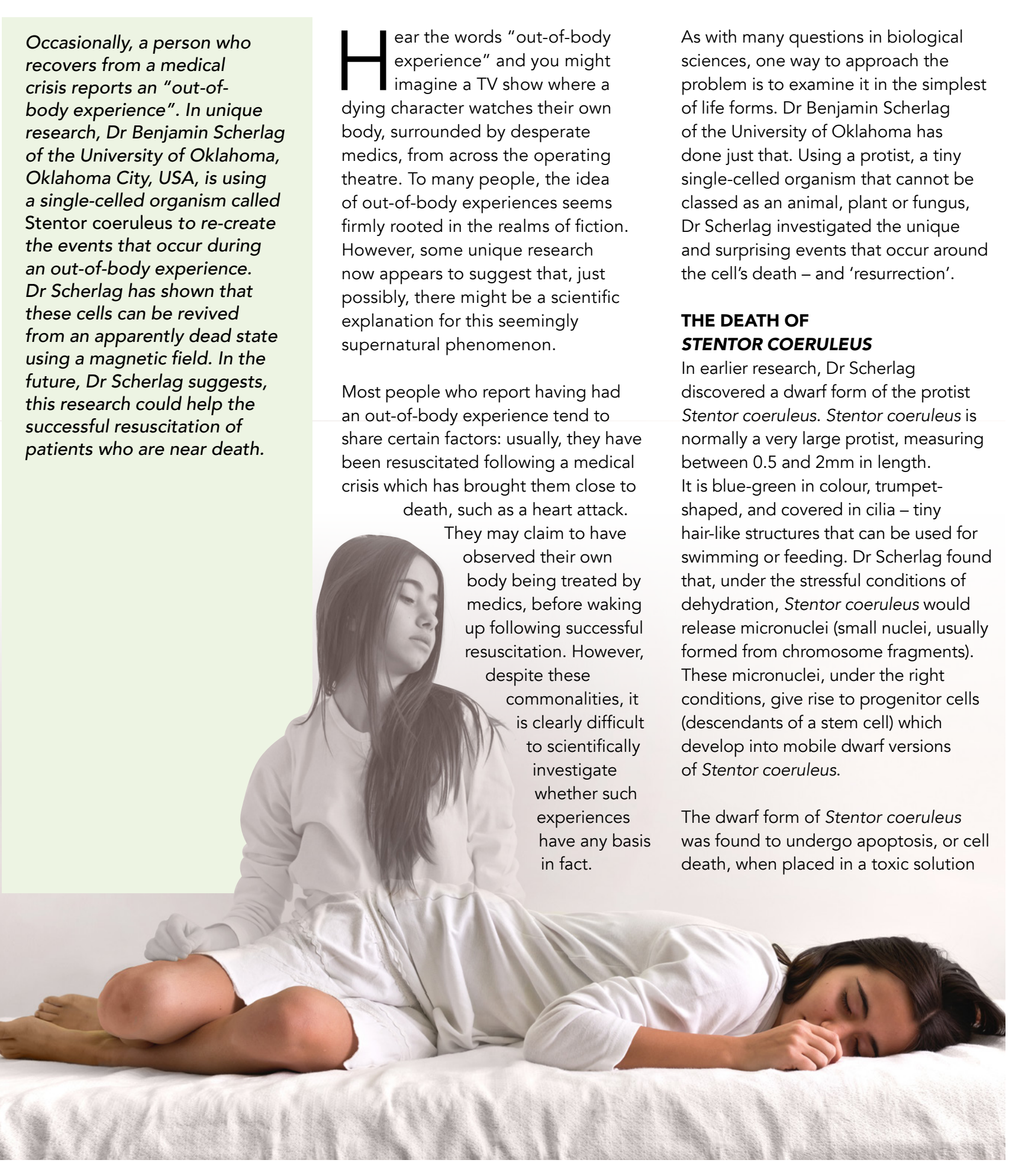

Occasionally, a person who
recovers from a medical crisis reports an "out-ofpatients who are near death.

Most people who report having had (n) certain factors: usually, they have m close to (a) coeruleus was found to undergo apoptosis, or cell

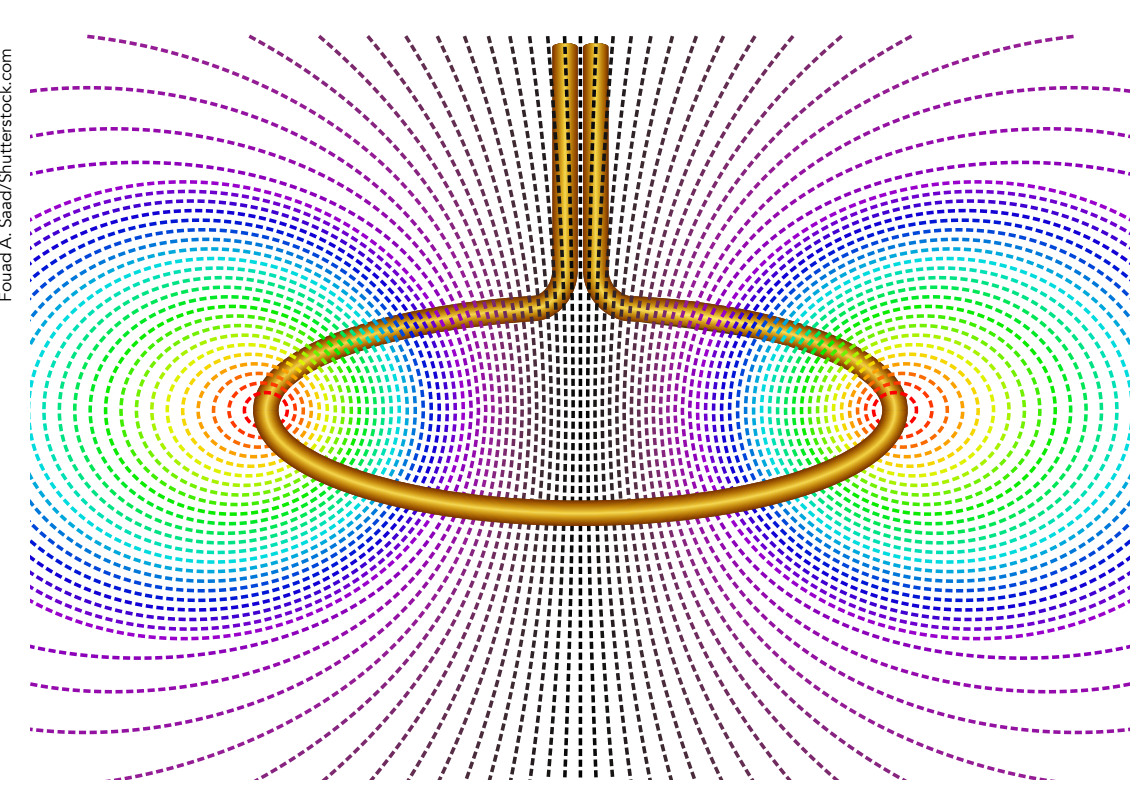

DrScherlag used magnetic for
retract back into the cells.

(chlorinated tap water.) Intriguingly, after cell death, Stentor coeruleus was be a replicate of itself. These replicates appeared around eight to ten minutes after the onset of apoptosis and survived for around 20 to 30 minutes before fading.

\section{BRINGING STENTOR}

Could the replicates created by the

dead or dying Stentor coeruleus

represent a persistence of life - an

out-of-body experience, at the cellular fhe cell death process?

After cell death, Stentor coeruleus was observed releasing what appeared to be a replicate of itself.

Dr Scherlag hypothesised that, if the replicate formation could be reversed, causing the replicate to retract back into the original cell, the apparently dead Stentor coeruleus could be returned to life. To test this idea, Dr Scherlag and his team added tap water to five samples of a liquid containing dwart Stentor coeruleus cells. A second group of five samples of Stentor coeruleus did not receive tap water and acted as a control. placed on a lide and obsens were placed on a slide and observed using to confirm that replice
can be reversed.

The samples containing the retracted cells were then placed in a growth medium (that did not contain any other cells), then divided between eight new slides. Over the following 24 to 48 hours the team continued to observe the samples. In this time, seven of the eight slides developed mobile dwarf Stentor coeruleus. These living organisms had appeared in samples (apparently) dead cells.

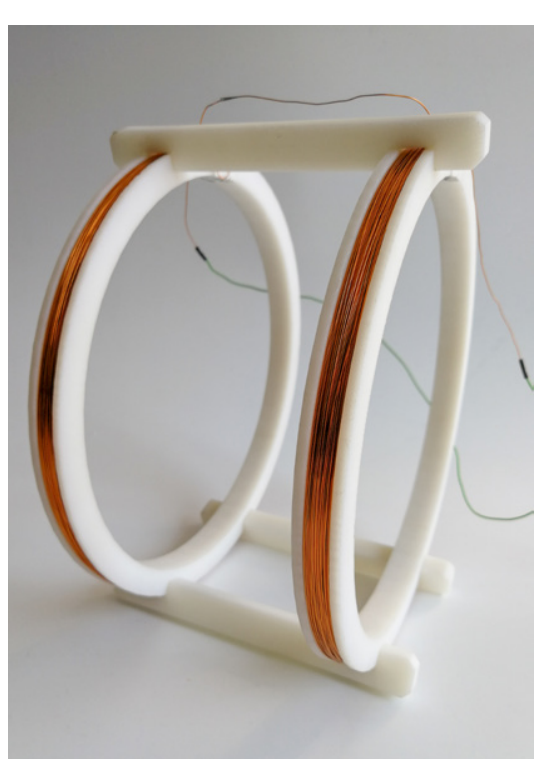

A Helmholtz coil which Dr Scherlag suggests
could help patients who are near death.

'RISING TO LIFE'

This study supports Dr Scherlag's ypothesis that causing the replicate cell can bring apparently dead Stentor coeruleus back to life. Other researchers have named this type of cellular restoration 'anastasis', which comes from the Greek meaning 'rising to life'. In religion, the word is often directly synonymous with 'resurrection' in medicine, it is sometimes used to describe a patient's recovery from serious illness.

Anastasis has been described as 'a process by which cells survive...

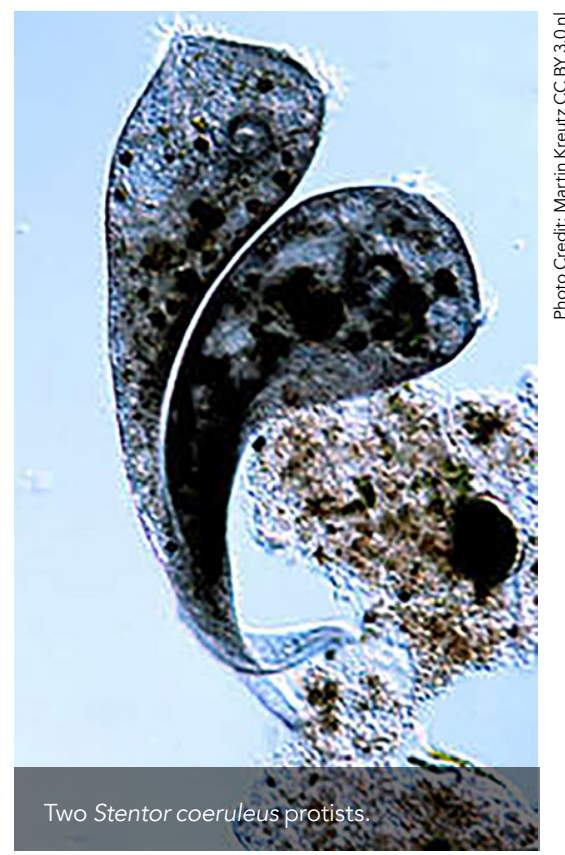




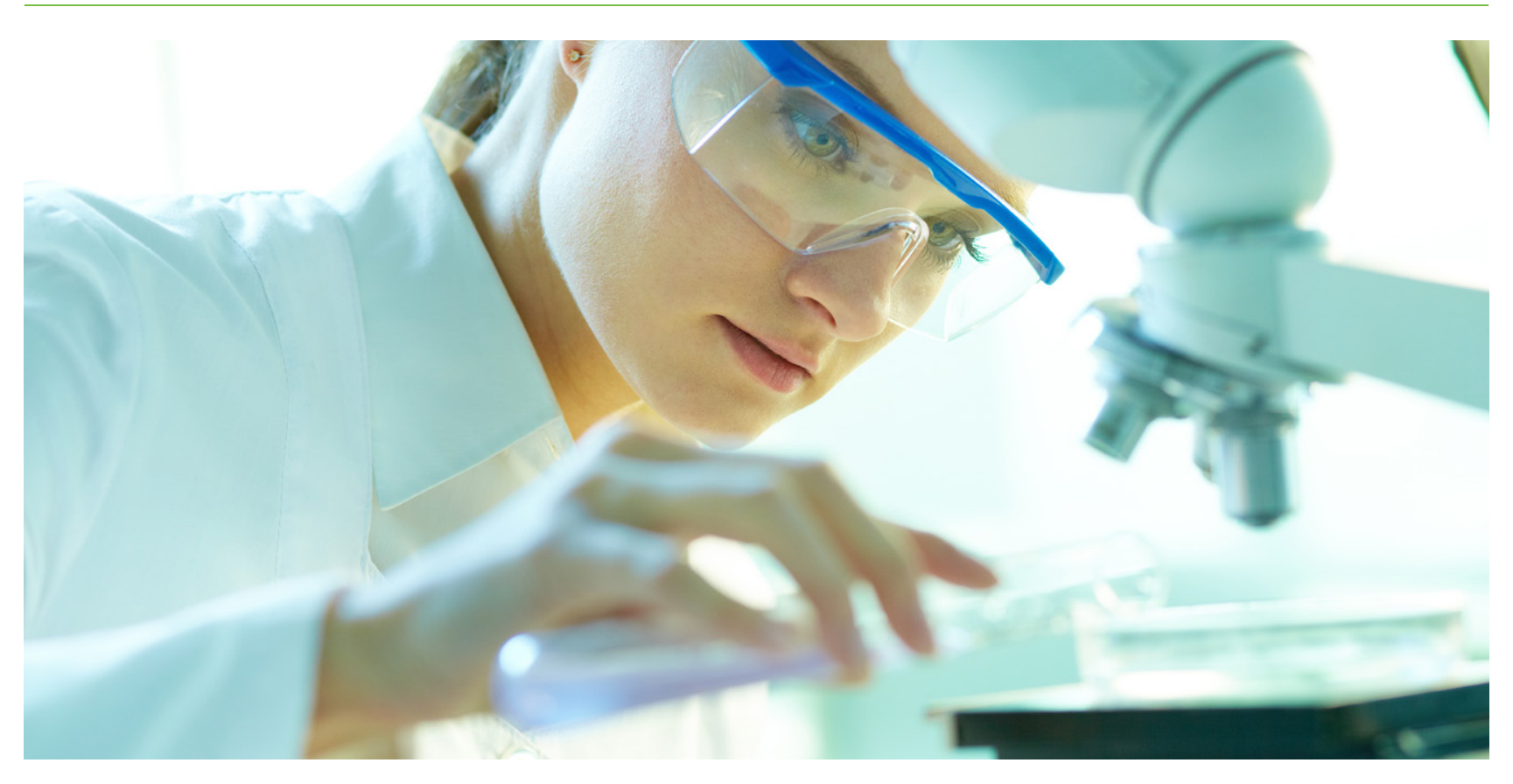

Causing the replicate to retract back into the original cell can bring apparentlydead Stentor coeruleus back to life.

following transient exposure to a lethal dose of an apoptotic stimulus'. One question is to what extent the cells can be said to be 'dead'; did Stentor coeruleus die, undergo an out-ofbody experience in the formation of replicates, then return to life through the application of a magnetic field? Or did it simply survive and recover from a series of damaging, but ultimately non-lethal, events? During apoptosis, an enzyme called 'executioner caspase' process. Dr Scherla acknowedges that the status of this enzyme in the

Stentor coeruleus that appeared to activated, the cell death pathway would not have been complete.

\section{COULD A MAGNETIC FIELD}

HELP SAVE PATIENT'S LIVES?

The existence of, and possible explanation for, out-of-body experiences in humans is clearly a controversial topic - and likely to remain so. But what are the possible clinical implications findingerlag's research? Could these lives of people who are close to death?

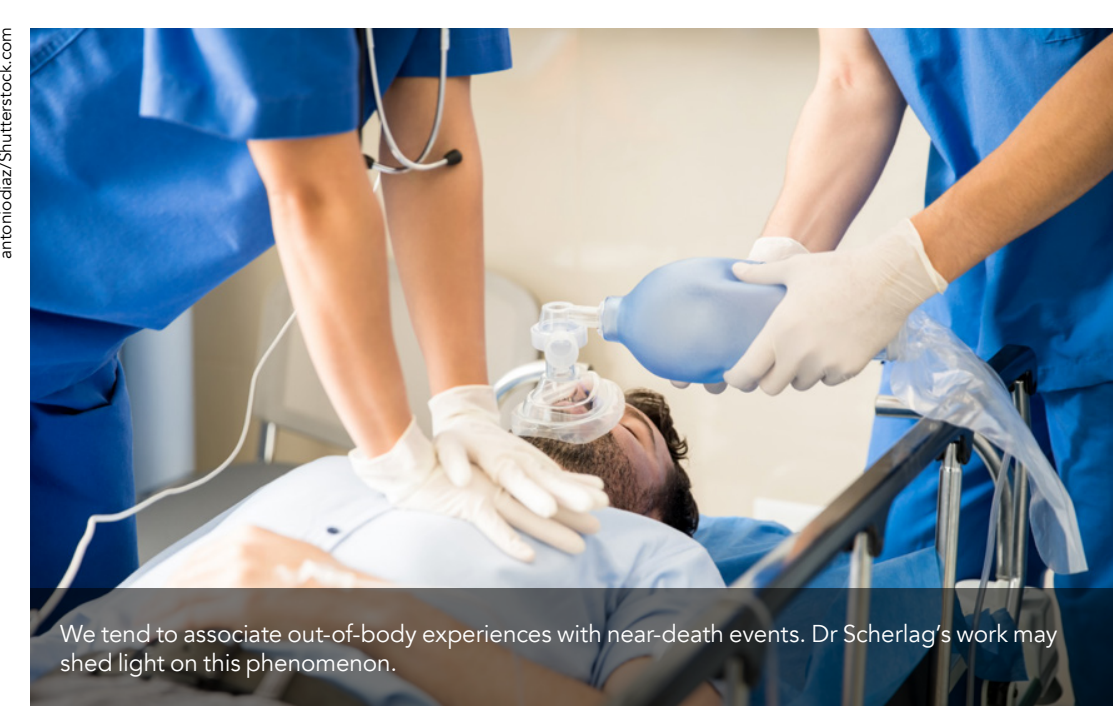

The results of Dr Scherlag's work With Stentor coeruleus could be said out-of-body experience, as it is usually reported around the time of death, a version of the cell or person leaves the original form, before returning following medical or scientific intervention Could Dr Scherlag's discovery that a magnetic field can restore Stentor coeruleus to life be translated to the field of human medicine? Dr Scherlag suggests that placing equipment such as a Helmholtz coil - a device that produces a controlled, uniform magnetic field - around the head of a patient undergoing resuscitation could (belp to force any out-or-body 'replicate' back into the physical body. The reason he dis ce would be placed around the resuscitation procedures.

This area of research, with its nod to the supernatural, is fascinating, unique and controversial. This particular study has not yet been published in a peer-reviewed journal (Dr Scherlag has published a study identifying the formation of Stentor coeruleus replicates in the journal Biosystems. Clearly, much more research is needed before any transference of this work to clinical practice is possible. Nevertheless, the mysterious events surrounding the formation, purpose surely offer the possibity
intriguing discoveries. and disappearance of cell replicates

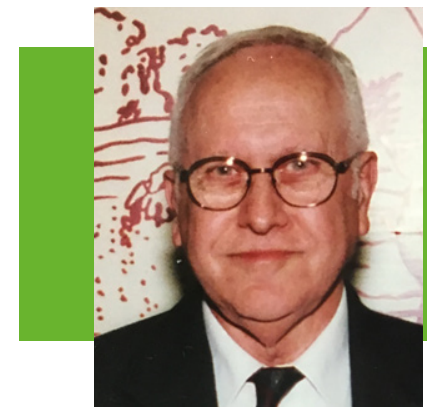

\section{Behind the Research}

\section{Dr Benjamin Scherlag}

E: benjamin-scherlag@ouhsc.edu T: +1405271 9696, ext. 37501

\section{Research Objectives}

Dr Scherlag investigates what happens to cells in a toxic environment and the parallels that can be drawn with (a)

\section{Detail}

Benjamin Scherlag

Department of Medicine

800 Stanton L. Young Blvd., suite 5400

Oklahoma City, OK, 73104

USA

Bio

Dr Scherlag is a Professor of Medicine at the

University of Oklahoma Health Sciences Center who is internationally known for experimental studies leading to the development of the recording of electrical activity from the His bundle in the heart in animals and in man.

Funding

ster foundation at th University of Oklahoma Research Foundation

\section{Collaborators}

Sey, MD, Sunny S. Po MD, PhD . Scherlag, BS, MBA

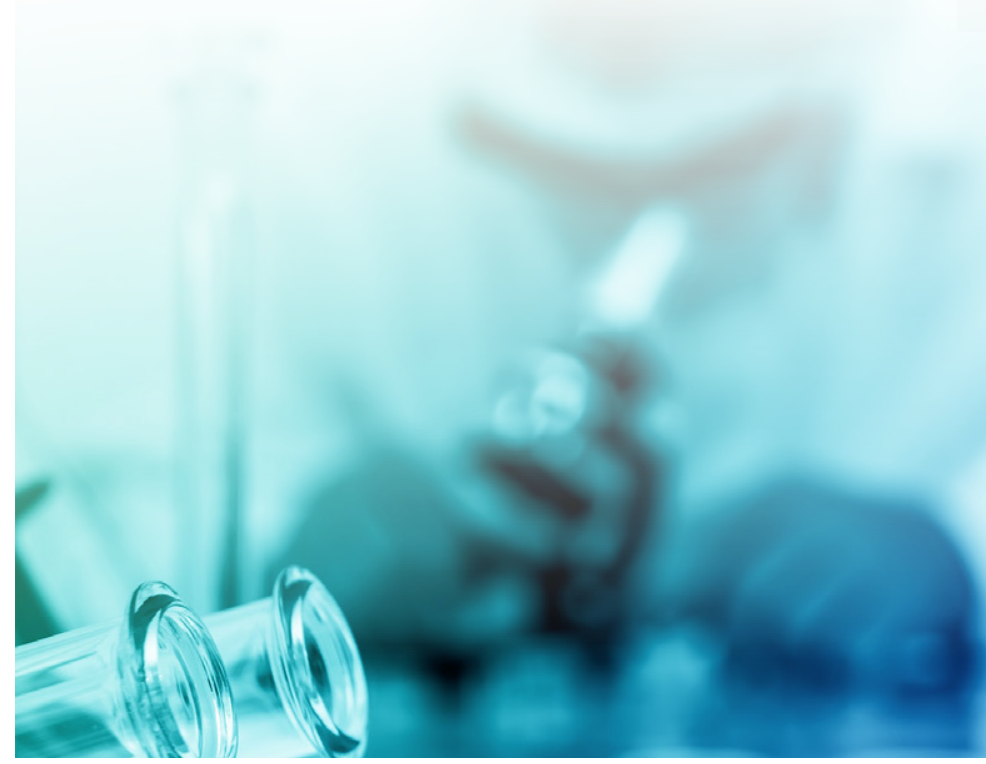

\section{References}

Scherlag, B.J. et al. (2019). Replicate Separation from Dead Dwarf Cells of Stentor coeruleus. Biosystems, 181, 27-30.

Personal Response

\section{Have similar events been observed in other types}

I/ Yes. Sun G., Montell D.J. Q\&A: Cellular near death experiences-what is anastasis? BMC Biol. 2017 (15) in multiple cultured cancer cell lines, including the cervical cancer cell line HeLa and the glioma leven after executioner caspase activation]... In vivo, in Drosophila, mammalian cardiac myocytes and neurons.. The discovery of anastasis in mammals and flies suggests that it is an ancient and evolutionarily conserved cellular process."

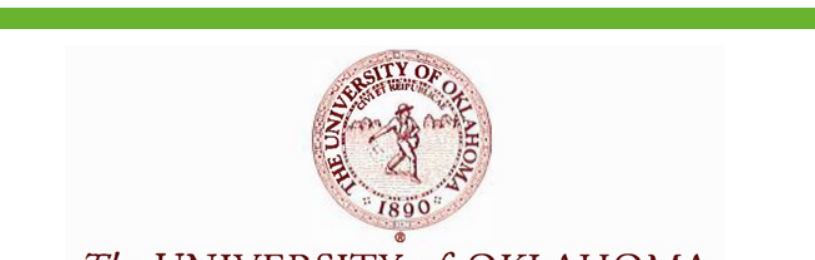

The UNIVERSITY of OKLAHOMA。 Health Sciences Center Cardiovascular Section 